\title{
Nine Questions for James S. Amelang
}

\section{James Amelang and Danièle Tosato-Rigo}

\section{(2) OpenEdition}

\section{Journals}

Electronic version

URL: http://journals.openedition.org/edl/888

DOI: $10.4000 /$ edl. 888

ISSN: 2296-5084

\section{Publisher}

Université de Lausanne

\section{Printed version}

Date of publication: 15 May 2016

ISBN: 978-2-940331-48-2

ISSN: 0014-2026

\section{Electronic reference}

James Amelang and Danièle Tosato-Rigo, " Nine Questions for James S. Amelang », Études de lettres

[Online], 1-2 | 2016, Online since 01 May 2019, connection on 15 December 2020. URL : http:// journals.openedition.org/edl/888 ; DOI : https://doi.org/10.4000/edl.888 


\section{NINE QUESTIONS FOR JAMES S. AMELANG}

1. Both microhistory and egodocuments have received much attention recently. However, the same cannot be said regarding the question of the relations between them, which strike many observers as promising yet uncertain. Would you agree?

There are many reasons to think of egodocuments - a particular type of historical source - and microhistory - a particular approach to or technique for framing historical research and writing - as fitting together closely. That said, if one surveys the major microhistories written to date, it is easy to get the impression that relatively few of them resort to egodocuments as their principal source. In other words, the fit between the two may be "natural", but it is hardly a given. And in any event, the question is not so much the snugness of their fit, but the ease with which historians can promote a synergy between them. When brought together by a talented and imaginative historian, they can promote forward movement, which is what we all should be pursuing. That said, one should have realistic expectations when considering working with either. Egodocuments are not rabbits one can pull out of a hat; they require deep labor, ranging from constant rereading to various contextualizations. Similarly, microhistory provides no shortcut in historical work. If anything it is the long way around a problem, as anyone who has tried to produce one can tell you. 


\section{What is the biggest temptation in individualizing history?}

I would mention risk before tackling temptation. The greatest risk, or even threat, that microhistory poses, according to those who have strong misgivings about it, is the ease with which it trivializes the past. "Trivialize" here means mistaking what is not that important in history for what is. For these critics, what is important - and which microhistory errs by ignoring - is the big picture, social, economic, political, whatever. And there are certainly some microhistories, as well as numerous small-scale, monographic works (biographies come readily to mind) that relegate the larger world to a lesser, background role of context, at best. I sympathize to some extent with this criticism, even if I doubt its relevance to the major works of Italian microstoria, whose attention to larger questions of historical substance, theory and method can hardly be ignored. I moreover think that we would all be better off were we to conceive of the task of the historian here not so much as requiring attention to background or context - the big picture I just alluded to - as much as to the big questions. In what may now well be the most widely read study of an individual (as well as the most famous microhistory) we have - Carlo Ginzburg's The Cheese and the Worms - the author is constantly reading and rereading and interpreting the truly unique experience of this truly unique individual to find what it can reveal about issues considerably beyond Menocchio's personal story and terrain. These range from the evolution of peasant culture over the very long run, to how to interpret Inquisitorial documents and other types of testimony, the different ways individuals read texts, and a host of other large and important questions. In other words, even when working on a small scale, what should drive historical research and analysis is larger aims, along with larger doubts and uncertainties. And it is easy to spot the difference between any microhistory - or any type of history, for that matter - that has such big questions moving it from one that lacks them.

As for temptation, the example of Ginzburg provides another lesson in what one could call microhistorical virtue (or self-control). Some time in the 1980s - I cannot remember exactly when now - I heard him give a talk at the History Department at Princeton University on a very unusual figure: Costantino Saccardino, a jester, distiller, unlicensed healer, and converted Jew who was executed by the Inquisition in Bologna in 
1622 for having defiled a street image of the Virgin Mary. Ginzburg slowly unravelled the different strands of his story, reconstructing from very fragmentary evidence - unlike the case of Menocchio, the original records and thus interrogations from his trial had not survived the life and purposes of a professional charlatan who, while dabbling in various occupations, was also trying to stir up artisans to revolt against the Church and other oppressors. Excitement was in the air, and the audience was delighted. But when someone asked the obvious question - when will the book on this new Menocchio come out? - Ginzburg surprised everyone by saying that he had decided not to pursue further the case of Saccardino. When asked why he was turning his back on such an interesting story, he replied that yes, the case was interesting, but was it important? ${ }^{1}$ I cite this whenever I hear anyone dismiss microhistory as trivial, sensationalist, or just interested in telling (and selling) a story. It fits in well with the insistence of Ginzburg and others like him that microhistory exists as a tool of exploration, as a means of putting to the test - it's no accident Italian microhistorians repeatedly use the metaphor of mettere a fuoco, which means (among other things) to put on the fire (while hinting of slow food) - in order to explore serious questions of method and analysis, and to think out new solutions to important problems. That said, Ginzburg's more recent work - let's say, ever since his dense and challenging "morphological» study of witchcraft known in English as Ecstasies $-{ }^{2}$ has turned in a different direction, abandoning large-scale exposition for individual essays tightly organized around posing and solving problems. The latter are often puzzles, which he resolves (at least in a preliminary way) by recourse to the "fundamental instrument" of "alienation, making strange, the ability to make the familiar alien. ${ }^{3}$ Despite all the obvious differences, the basic premises and

1. My italics. Ginzburg published (along with Marco Ferrari) a brief sketch of the themes at play in Saccardino's tale as "La colombara ha aperto gli occhi", Quaderni storici, 38, 1978, pp. 631-39; Edward Muir and Guido Ruggiero included it as "The Dovecote Has Opened Its Eyes", in their valuable anthology Microhistory and the Lost Peoples of Europe, trans. Eren Branch, Baltimore: Johns Hopkins University Press, 1991, pp. 11-19.

2. Ecstasies: Deciphering the Witches' Sabbaths, New York: Penguin, 1991. The original version was published in 1989 as Storia notturna (Turin: Einaudi).

3. Cited in Hans Medick's wide-ranging essay "'Missionaries in the Rowboat'? Ethnological Ways of Knowing as a Challenge to Social History», in Alf Lüdtke (ed.), 
purposes of microhistory are still much in evidence, especially the central dynamic of the methodical probing of what looks at first sight to be a singular, even eccentric historical experience, text, or testimony. And as before, patient questioning - once again slow food comes to mind has a metamorphosising effect, challenging standard understandings, or revealing nuances and linkages that had not been spotted before. While few of these essays come close to recreating the powerful impact that The Cheese and the Worms had on readers, the more effective among them map out brief but intense journeys of estrangement followed by return to categories and concepts that thereafter are taken less for granted.

3. You encountered The Cheese and the Worms when you were a graduate student. What impact did this book have on you?

I had the immense good fortune of reading The Cheese and the Worms shortly after it first came out in 1976. Ginzburg had originally presented a version of it as a paper at Princeton, and my adviser there, Ted Rabb, tipped me off very soon after its publication. I had already read Ginzburg's first book, I Benandanti (1966), but still, I was not prepared for the impact that this new work would have on me. Starting with the preface, with its energetic checklist of virtually every mistake and false step that had been made in studying popular culture, all the way through the footnotes, which introduced me to a combination of erudition and intellectual liveliness that I hadn't realized was possible, I was bowled over by every page I read. And like everyone else, I felt immediately drawn to the irascible and sympathetic figure of Menocchio, and his extravagant but appealing understanding of how the world and everything else was created. Ironically, it was only through repeated readings - which came largely from teaching the book over the years in a wide range of courses - that I made my way to and through the "theory» in the text. ("Theory» in Ginzburg's work began for me in his "Clues» essay, originally published in 1979, which was the first major entry in the series of remarkable essays that he has continued to produce until the present). Back then I saw The Cheese and the Worms more

The History of Everyday Life: Reconstructing Historical Experiences and Ways of Life, trans. William Templer, Princeton: Princeton University Press, 1995, p. 49. 
as exemplary practice - and a well told, even compelling story - than theory. I am older now, and would not separate the two into opposing strands, even if deft interweaving of opposites is one of Ginzburg's many literary gifts.

4. Was the idea behind your study of popular egodocuments The Flight of Icarus (1998) linked to your reading of Ginzburg? Or to the new interest of historians in autobiographical writing?

Yes, reading Ginzburg certainly helped shape my book on popular autobiography. One could not have worked then - or even now, I would say - on any aspect of early modern popular culture without being inspired by his work, and by that of Natalie Davis, E.P. Thompson, Peter Burke, Bob Darnton, Roger Chartier, and many others. That said, The Flight of Icarus did not start out as the general study it eventually became. Its point of departure was a single text, which I subjected to a single question. The text was an urban chronicle written by the master tanner Miquel Parets from 1626 to 1660 that all historians of early modern Barcelona were familiar with, but which they mined exclusively for information. My question was why on earth did a tanner devote so much time and effort to writing it? In my extreme naiveté I assumed that the answer to this question lay in the author's own life, and I thus began to explore the local archives in order to reconstruct his biography and circumstances. While this was great fun, it did not take me long to realize that such a limited approach would not furnish me with the answers (now in plural) I was looking for. Luckily for me, I found decisive help from several studies that appeared very opportunely to suggest that the case of Parets and those of other artisan autobiographers were admittedly unusual, but hardly unique. (Especially instructive were Thomas Platter's classic autobiography, Alain Lottin's study of the Lille chronicle of Pierre-Ignace Chavatte, Paul Seaver's short but suggestive book on Nehemiah Wallington, and above all Daniel Roche's edition and studies of the Journal of Jacques-Louis Ménétra) ${ }^{4}$. Thus, broadening the field of

4. My command of Swiss German being non-existent, I read Platter in the French translation by Marie Helmer in the Cahiers des Annales series (Autobiographie, Paris: Armand Colin, 1964); I suspect that I am not the only reader who was disappointed 
observation led to broadening the questions I wound up posing. I have my doubts about many of the answers I offered, but I was pleased that more colleagues than I expected found the end results useful.

5. Your study of the journal of Miquel Parets seems to combine egodocuments and microhistory. Are there precedents for such an approach?

Actually, my view is that while The Flight of Icarus comes close to microhistory in several respects, it lacks several vital elements that are needed in microhistory, at least in the way the Italian founders of the technique envision it. (I stated as much in the preface). Where it comes nearest to the works that appear in the Microstorie series published by Einaudi and when the history of microhistory is finally written I daresay that the question of the choice and reception of the books in that series will play an important role - is in the chapter devoted to the various and overlapping urban contexts in which Parets lived. Whatever one calls it - contextual reconstruction, background to biography, nominal record linkage, what have you - the aim was to bring classic social history to bear on a single, individual case. In other words, my target was not a social field, like the property-owners in Giovanni Levi's extraordinary study of a seventeenth-century Piedmontese village, or Paul Boyer and Stephen Nissenbaum's equally impressive reconstruction of the conflicts among their near-contemporaries in Salem, Massachusetts. ${ }^{5}$ Rather, I tried to apply some of the techniques they used to locate my artisan author in some of the same contexts, albeit on a smaller scale. And it was within these loosely-knit circles that I located - or rather, speculated about - the types of social and political experiences they sustained, and

by Emmanuel Le Roy Ladurie's later and much larger book on the Platter family. The other references are: Alain Lottin, Chavatte, Ouvrier Lillois: Un Contemporain de Louis XIV, Paris: Flammarion, 1979; Paul S. Seaver, Wallington's World: A Puritan Artisan in Seventeenth-Century London, Stanford: Stanford University Press, 1985; and JacquesLouis Ménétra, Journal de ma Vie, ed. Daniel Roche, Paris, Montalba, 1982 (translated into English in 1986).

5. Giovanni Levi, L'eredità immateriale: Carriera di un esorcista nel Piemonte del Seicento, Turin: Einaudi, 1985 (Eng. trans. 1988); Paul Boyer and Stephen Nissenbaum, Salem Possessed: The Social Origins of Witchcraft, Cambridge MA: Harvard University Press, 1974 (Ital. trans. 1986). 
which could have both enabled and stimulated Parets' act of authorship. I found no smoking pistol, to be sure. Then again, if I began my research hoping that one existed, I finished it having learned that it did not, nor could it have. This was modest progress, to be sure, but welcome all the same.

\section{Are there different types of microhistory? If so, how do they differ?}

The distinction most commonly made is between two variants of microhistory. The first, what one could call a social microhistory, is exemplified by the book by Giovanni Levi I just alluded to, or by some of the publications of Edoardo Grendi, who is not always given the credit due him as one of the pioneers of this type of history. ${ }^{6}$ Ginzburg is by far the best known exponent of the other type, what could be called (again, for lack of a better name) a cultural microhistory. Many pages could be written about how misleading a distinction this is. ${ }^{7}$ The important point to register is, I believe, that there is no single, much less canonical way of thinking and doing microhistory. Rather - as Ginzburg, Levi, and many others have pointed out repeatedly in their writings - microhistory emerges when any historian makes a conscious effort not only to reduce the scale of analysis but also to welcome and to test whichever unpredictable or difficult results such an experiment generates.

That said, the Italian founding fathers are quick to distinguish their approach(es) from many others who have adopted the brand name without taking on its theoretical rigor. My fellow Americans loom especially large as culprits here, and have come in for harsh words (or rapid dismissal) for their reducing microhistory simply to telling stories or

6. Grendi's crucial theoretical contribution was his "Micro-analisi e storia sociale», Quaderni Storici, no 35, 1977, pp. 506-520, along with his follow-up «Ripensare la microstoria?", Quaderni storici, no 86, 1994, pp. 539-549. I would also strongly urge interested readers to would also strongly urge interested readers to consult the posthumous collection of his essays edited by Osvaldo Raggio and Angelo Torre, In altri termini: Etnografia e storia di una società di antico regime, Milan, Feltrinelli, 2004.

7. For a valuable exploration of this issue, see Simona Cerutti, «Microhistory: Social Relations versus Cultural Models?", in Anna-Maija Castrén, Markku Lonkila and Matti Peltonen (eds.), Between Sociology and History: Essays on Microhistory, Collective Action, and Nation-Building, Helsinki: SKS-Finnish Literature Society, 2004, p. 17-40. 
reconstructing biographies. While Levi in particular has levelled strong criticisms at what he refers to as the "dangers of Geertzism " ${ }^{8}$, one senses a broader dissatisfaction over the way in which microhistory has become more of a fashion or buzzword than the stimulus to the broader aim of revisioning historical epistemology and practice that its original proponents had in mind.

7. Which "recommended readings" about microhistory should we be sure to share with our students?

The bibliography on microhistory continues to grow, but I believe one is best off starting with the earlier discussions. Classic writings on, and criticisms of, microhistory include:

Levi, Giovanni, "On Microhistory», in New Perspectives on Historical Writing, ed. by Peter Burke, Cambridge, Polity Press, 1991, p. 93-113.

Muir, Edward, "Introduction: Observing Trifles», in Microhistory and the Lost Peoples of Europe, ed. by Edward Muir, Guido Ruggiero, Baltimore, Johns Hopkins University Press, 1991, p. VII-XXVIII. Ginzburg, Carlo, «Microhistory: Two or Three Things That I Know About It ", Critical Inquiry, 20 (1993), p. 10-35.

Revel, Jacques (éd.), Jeux d'échelles: La micro-analyse à l'expérience, Paris, Gallimard-Seuil, 1996.

Grogory, Brad S., "Is Small Beautiful? Microhistory and the History of Everyday Life", History and Theory, 38 (1999/1), p. 100-110.

Medick, Hans, «Weaving and Surviving at Laichingen 1650-1900, or: Micro-History as History as a Research Experience", in Agrarian Studies: Synthetic Work at the Cutting Edge, ed. by James Scott, New Haven, Yale University Press, 2001, p. 283-296.

Brewer, John, "Microhistory and the Histories of Everyday Life», Cultural and Social History, 7 (2010), p. 1-16.

8. Giovanni Levi, «I pericoli del geertzismo», Quaderni storici, no 58, 1985, pp. 269277; see also the preceding essay by Philip Benedict, "Storia interpretativa o storia quantitativa?", on pp. 257-269. 
Trivellato, Francesca, «Is There a Future for Italian Microhistory in the Age of Global History?", California Italian Studies, 2 (2011/1), p. 1-26.

—, "Microstoria/Microhistoire/Microhistory», French Politics, Culture \& Society, 33 (2015), p. 122-134.

Magnússon, Sigurður Gylfi, Szijártó, István M., What is Microhistory? Theory and Practice, London, Routledge, 2013.

\section{What about the connections between microhistory and global history?}

Obviously many people are wondering these days about the future of microhistory as global history - the most macro of human stories continues to expand its domain. How they can be related has already produced some very interesting reflections, ranging from Francesca Trivellato's thoughtful essay cited above - and note that the reference to Italian Microhistory in her title does not refer to work just on Italy, but rather denotes microstoria as an approach that differs from what passes as microhistory elsewhere, especially in the English-speaking world - to John-Paul Ghobrial's ongoing research on a Syrian monk who wound up writing the first history of Latin America written in Arabic (!) In fact, these and other scholars will be convening in Venice in late February to discuss precisely the topic of the relations between these two approaches to historical research and writing. The high point of the gathering promises to be a round table featuring the fathers - or more precisely, now the grandfathers - of microhistory, Giovanni Levi, Jacques Revel, and Hans Medick (Ginzburg could not attend, but he has already published on the subject). ${ }^{9}$ Needless to say, we can look forward to a wide range of possible linkages. Some of the earliest work deliberately to bring the macro-micro bookends together has involved inserting the oldest form of individualizing history - biography - into global settings, as in Linda Colley's engaging reconstruction of the eighteenth-century life

9. Carlo Ginzburg, "Microhistory and World History", in Jerry H. Bentley, Sanjay Subrahmanyam and Merry E. Wiesner-Hanks (eds.), The Cambridge World History, Cambridge: Cambridge University Press, 2015, pp. 446-473. For Ghobrial's work in progress, see his "The Secret Life of Elias of Babylon and the Uses of Global Microhistory", Past and Present, no 222, Feb. 2014, pp. 51-93. 
of Elizabeth Marsh, which ranged from the West Indies to East India. Other possibilities opt for the opposite tactic: starting with the global dimension, and then unwinding it by focusing on a single individual or object, as in Robert Batchelor's latching onto a single map as a means of reconstructing the slow and painful acquisition of geographical knowledge of China by English merchants and scholars in the sixteenth and seventeenth centuries. ${ }^{10}$ The possibilities are endless, and what seems clear here at the beginning is that micro and macro histories are not so much rivals for historical attention, but rather natural allies when properly brought to bear on historical questions.

\section{What does the future of all this look like?}

I am old enough to remember my undergraduate history teachers expressing doubts about using autobiographies as sources because they were too subjective, and young enough that I heard next to nothing of this sort when I went to graduate school a few years later. That is, I am part of a generation that grew up believing in the existence of "objective" history, which is something that we slowly unlearned in the years that followed. These latter years saw major transformations in the profession of history, some very welcome - the rise of cultural or women's history, for example - and some less so. I try to be as optimistic as possible about the changes that continue to take place in our ways not only of understanding the past, but also in our efforts to communicate knowledge about this changing timescape. Both the consolidation of microhistory and the growing attention to egodocuments as sources strike me as justifying this optimism. To return to a point I alluded to at the beginning, both are promoting forward movement, outward linkages, more intense contact across fields, and other results of what we could call historiographic good practices. But to be frank, I see some risks as well. One that increasingly worries me is the way different types of history today seem increasingly to detach themselves from the other varieties of history. This is partly the consequence of the hyper-specialization

10. Linda Colley, The Ordeal of Elizabeth Marsh: A Woman in World History, New York: Pantheon, 2007; Robert K. Batchelor, London: The Selden Map and the Making of a Global City, 1549-1689, Chicago: University of Chicago Press, 2014. 
that is taking place everywhere, and which everyone laments, but no one knows how to stop. And I am especially worried about the way the juggernaut of cultural history in particular is rapidly shedding its formerly strong links with social history. A solid, scientific knowledge - not just everyday common sense - of how society works is precisely what allows one to tell norms from exceptions, to spot anomalies within discourse and practice, and to explore the logic and rules of individual and collective behavior. I firmly believe that a close familiarity with social as well as economic, political, and other realities is needed to keep cultural history from getting too theoretical and ethereal - and repetitive and predictable. Certainly a strong grounding of this sort was something that distinguished the cultural historians from whom I have learned the most, which includes the microhistorians and egodocumentarians I have mentioned above. Thanks to their example, I do feel more confident about our uncertain but shared future.

Interview by Danièle Tosato-Rigo 12th February 2016 
